\title{
Optimal Sizing and Control Strategy of renewable hybrid systems PV-Diesel Generator-Battery: application to the case of Djanet city of Algeria
}

\author{
Adel Yahiaoui ${ }^{*}, 1$, Khelifa Benmansour ${ }^{1}$, Mohamed Tadjine ${ }^{2}$ \\ ${ }^{1}$ Research Laboratory of Electrical Engineering and Automatics, Electrical Engineering Department, Yahia Fares University, \\ Medea, Algeria
}

${ }^{2}$ Control Laboratory Processes, National Polytechnic School, 10 Avenue Hassen Badi, BP.182, El-Harrach Algiers, Algeria

\begin{tabular}{l} 
A R T I C L E I N F O \\
\hline Article history: \\
Received: 26 March, 2017 \\
Accepted: 11 May, 2017 \\
Online: 24 May, 2017 \\
\hline Keywords: \\
Optimal size \\
Photovoltaic systems \\
Partial discharges \\
Urban areas \\
Hybrid power systems \\
\hline
\end{tabular}

\begin{abstract}
A B S T R A C T
A method for optimal sizing of hybrid system consisting of a Photovoltaic (PV) panel, diesel generator, Battery banks and load is considered in this paper. To this end a novel approach is proposed. More precisely a methodology for the design and simulation of the behavior of Hybrid system PV-Diesel-Battery banks to electrify an isolated rural site in southern Algeria Illizi (Djanet). This methodology is based on the concept of the loss power supply probability. Sizing and simulation are performed using MATLAB. The technique developed in this study is to determine the number of photovoltaic panels, diesel generators and batteries needed to cover the energy deficit and respond to the growing rural resident energy demand. The obtained results demonstrate the superior capabilities of this proposed method.
\end{abstract}

\section{Introduction}

PV system size and performance strongly depend on meteorological variables such as solar energy, wind speed and ambient temperature and therefore, to optimize a PV system, extensive studies related to the metrological variables have to be done [1].

The performance of a PV module strongly depends on the sun light conditions. Standard sunlight conditions on a clear day are assumed to be $1000 \mathrm{~W}$ of solar energy per square meter and it is sometimes called "one sun" or a "peak sun'. Less than one sun will reduce the current output of a PV module by a proportional amount $[2,3]$.

The generation of electricity through a hybrid system combining several renewable energy sources is of great interest to developing countries, Such as the Maghreb countries. These countries have many isolated regions far from traditional electricity distribution networks. Thus the extension of these networks would be of an exorbitant financial cost. To solve this problem, exploiting the renewable energy potential of these countries must be a priority.

Hybrid PV/diesel systems have greater reliability for electricity production than using PV system alone because diesel engine production is independent of atmospheric conditions. The

*Corresponding Author: Adel Yahiaoui, City of Almond, Bougara, Blida, Algeria +213795517302 | Email: yahiaoui.industry@gmail.com
PV/ diesel system will provide greater flexibility, higher efficiency and lower costs for the same energy quantity produced. In addition, PV/diesel system as compared to only diesel system provides a reduction in the operation costs and air pollutants emitted to the atmosphere [4]. Currently, some research works are carried out focusing on optimal sizing of hybrid PV/diesel generator systems so that the number of PV modules, storage battery capacity and diesel generator capacity can be optimally selected. Hybrid PV/diesel systems can be classified into two categories: series topology and parallel topology. In the series topology, the diesel generator is connected in series with the inverter and therefore it is not able to supply the load directly while the load demand is covered by the storage battery. The disadvantages of this topology that such systems require large inverter size and low overall efficiency due to the series connection, as well as when the PV system is connected to the diesel generator it leads to a limited control of the diesel generator. However, these disadvantages can be avoided in the parallel topology whereas the diesel generator is in parallel with the inverter and can supply the load and the battery at the same time [4].

Rural electrification in the southern countries is based in most cases on solar homes systems with limited use. This gives an impression that photovoltaic systems aimed the poor. Diesel generators generate more electricity but suffer from the maintenance costs and the provision of oil [5]. 
The hybrid combination of photovoltaic-battery-diesel systems requires technical knowledge, economic and preliminary studies for the design, optimizing the choice of a suitable load profile, assessing consumption and simulation performance before installation and implementation of the systems. Each aforementioned item requires data and computer tools to accomplish it.

Many papers are discussed on design of hybrid systems with the different components. In 2006 Eftichios Koutroulis et al presented a methodology for optimal sizing of stand-alone PV/WG systems using genetic algorithms [6]. They applied design approach of a power generation system, which supplies a residential household. In 2007 Yang developed a novel optimization sizing model for hybrid solar-wind power generation system [7]. In 2016 R. Hosseinalizadeh et al presented an economic sizing of a hybrid (PV-WT-FC) renewable energy system (HRES) for stand-alone usages by an optimizationsimulation model: Case study of Iran [8]. In 2015 B. Guinot developed a Techno-economic study of a PV-hydrogen-battery hybrid system for off-grid power supply: Impact of performances' ageing on optimal system sizing and competitiveness [9]. Recently, Leong Kit Gan et al developed a hybrid windphotovoltaic-diesel-battery system sizing tool development using empirical approach, life-cycle cost and performance analysis: A case study in Scotland [10].

An overall power management strategy is designed for the system to coordinate the power flows among the different energy sources. Simulation studies have been carried out to verify the system performance using practical load profile and real weather data in south Algeria. It is to mention that there are many similar regions around the world with this typical situation that can be expanded.

In this paper, a methodology of optimal sizing of hybrid power generation system is proposed. The main objective of this work is to determine the optimal number of PV panels, Battery banks and diesel generators. For this purpose a new sizing algorithm, called loss power supply probability (LPSP) is utilized. The obtained results show that the proposed methodology finds optimal sizing of hybrid power generation system with a quality energy services for the rural population through of a reliable network. The simulated result illustrates the good applicability and performance of the proposed method.

The rest of the paper is organized as follows: Section 2 presents the city of our study. Section 3 presents the modeling of the system considered. Section 4 discuses about the LPSP algorithm. Section 5 and 6 describes how the problem can be solved by using the proposed method and results. Conclusions are presented in Section 7.

\section{The case of Djanet city}

\subsection{The selected site}

The site selected for this study is a rural village isolated Saharan named "Djanet" present in figure 1. This village is located in the province of Illizi and consists of a small number of homes.

\subsection{Meteorological data}

The performances of photovoltaic modules are directly correlated to climatic data that is in principle the solar irradiation and the ambient temperature. These data are taken through the acquisition system measured to step time is 10 minutes. For each day of the year the kit provides for the acquisition of ambient temperature in degrees Celsius $\left({ }^{\circ} \mathrm{C}\right)$, and solar incident in Watts per square meter illumination (W/ $\mathrm{m} 2$ ). The annual assessment of the site's climatic characteristics is shown in Figure 2 and Figure 3 .
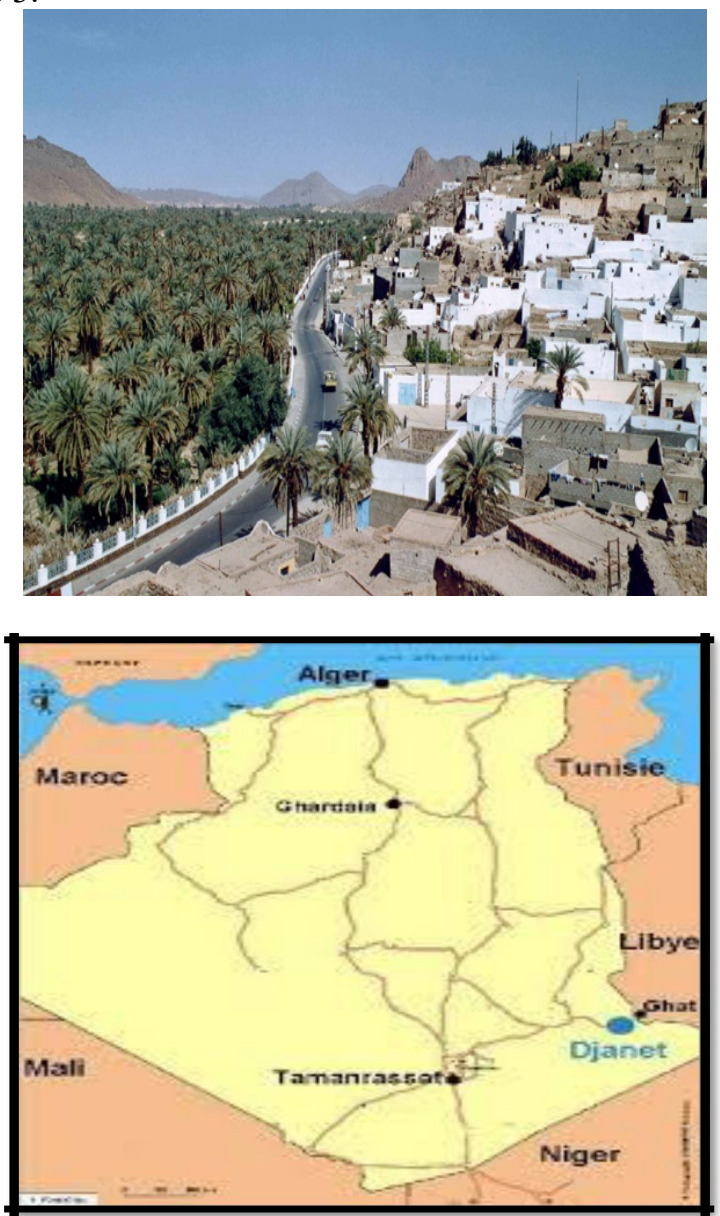

Figure 1: Geographical location of Djanet city in Algeria

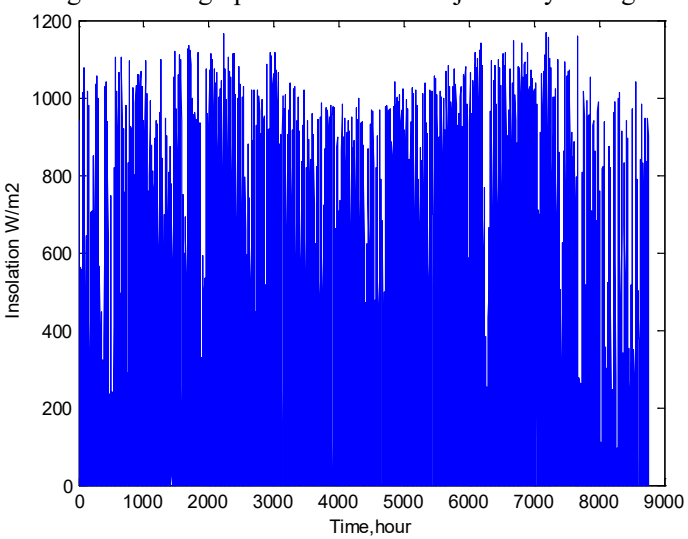

Figure 2: Annual insolation data for Djanet city

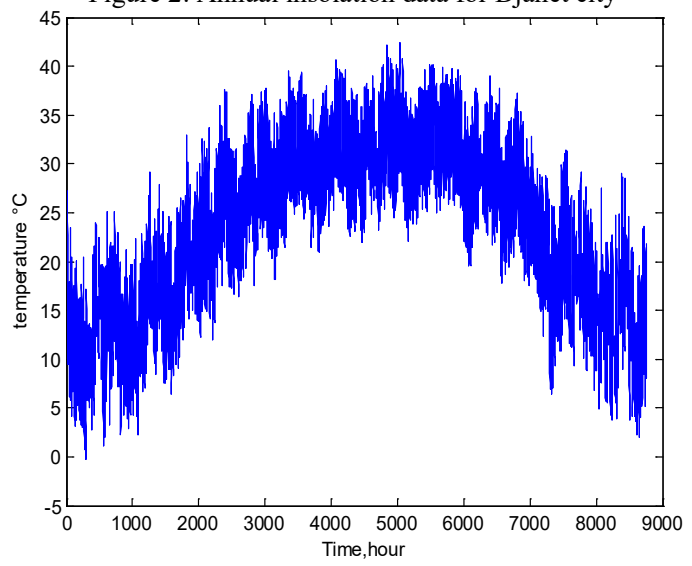

Figure 3: Annual temperature data for Djanet city 


\subsection{The load profile}

The initial data in the implementation of a renewable energy production system as for any other energy system is the demand, which will be determined in relation to the and / or the loads to be supplied. This demand must be estimated as precisely as possible, both from a point of view of the powers called and from its temporal distribution, although it's often random nature makes this task very difficult.

The hybrid system considered is intended for supplying a load for domestic use. For our case study (Djanet city) in which there are ten dwellings, we consider a constant load profile throughout the year.

Figure 4 shows the distribution over the hours of the day of consumption of the conventional appliances used (lighting, refrigeration, $\mathrm{TV}$, radio, ventilation); on which the difference between the quantities of energy consumed from one hour to another is seen. Hence, the importance of choosing economical appliances for isolated sites, to minimize installation costs.

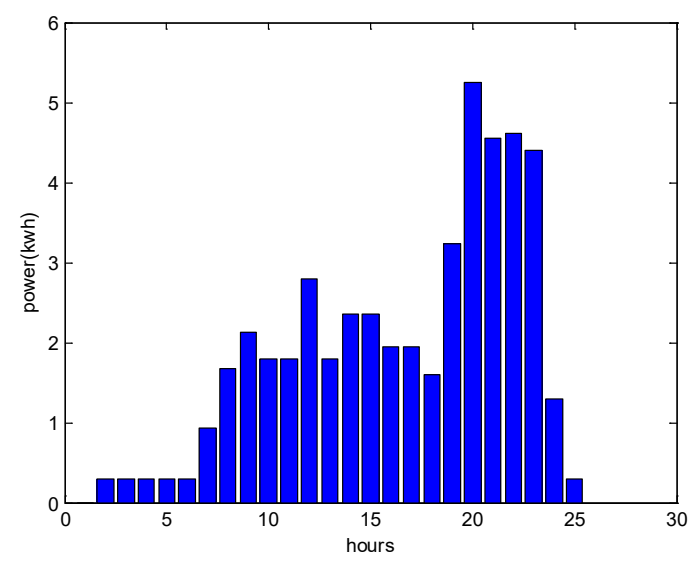

Figure 4: Curves of hourly load profiles.

\section{Modeling of considered system}

\subsection{Photovoltaic system}

Choosing a suitable model for simulation is very essential. The simple model of PV panel as a function of the area, the input variables of this model are solar insolation shown in Figure 1 and its efficiency. Detail equation of PV model can be described as follows $[10,11,12]$ :

$$
P_{p v}(t)=n \cdot A_{p} \cdot N_{p v} \cdot G(t)
$$

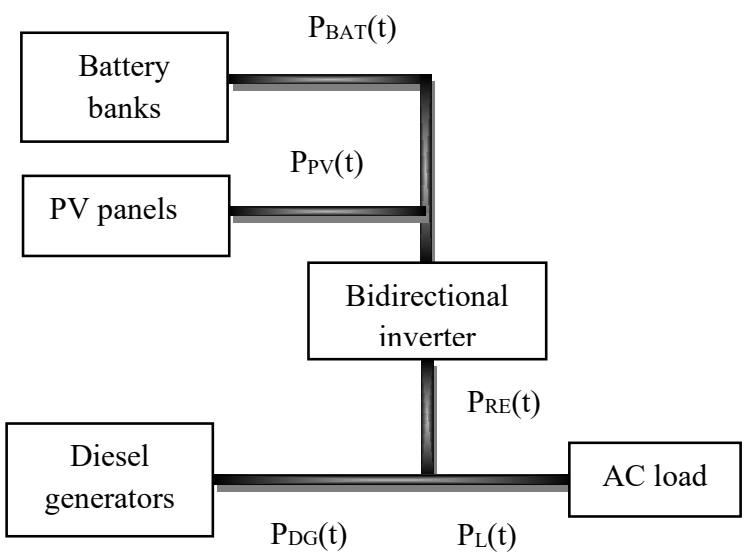

Figure 5: Configuration of the system
Where; $n$ energy conversion efficiency, $(\%) . \mathrm{A}_{\mathrm{p}}$ is the area of single PV panels, $\left(\mathrm{m}^{2}\right) . \mathrm{N}_{\mathrm{pv}}$ is the number of PV panels. $\mathrm{G}(\mathrm{t})$ is the insolation data, $\left(\mathrm{W} / \mathrm{m}^{2}\right)$.

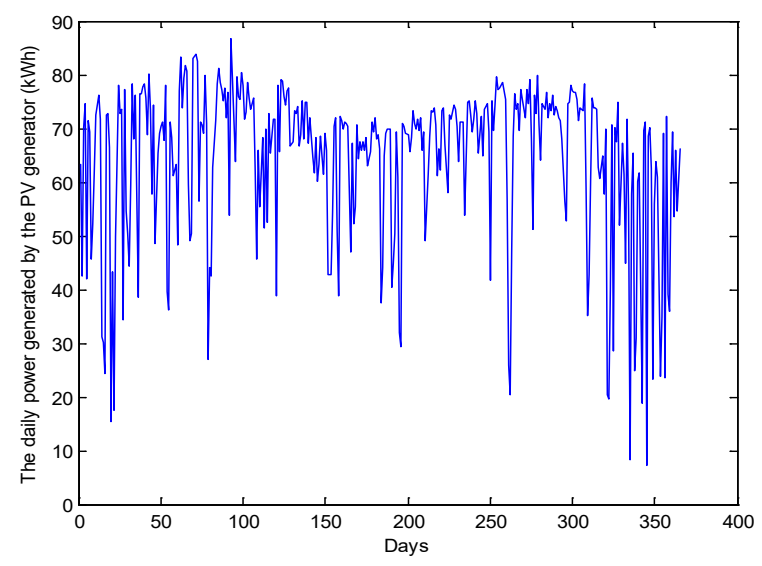

Figure 6: The daily power generated by PV modules

\subsection{Battery Banks}

Here, power from battery banks is required whenever The PV panels or Diesel generators $\left(D_{\mathrm{s}}\right)$ are fail to supply load. Power from PV system through the inverter is hourly measured as follow:

$$
P_{R E}(t)=\eta_{i n v} . P_{p v}(t)
$$

Where, $\eta_{i n v}$ is the inverter efficiency. Principles of charging and discharging scenarios are dependent on the state of $P_{\mathrm{RE}}$ and the load power demand at hour $\mathrm{t}\left(\mathrm{P}_{\mathrm{L}}(\mathrm{t})\right)$.

1. If the value of $P_{R E}(t)>P_{L}(t)$ the remaining power will be used to charge battery banks by the following equation [13]:

$$
C_{B a t}(t)=C_{B a t}(t-1)+\left(P_{p v}(t)-\frac{P_{L}(t)}{\eta_{i n v}}\right) \eta_{B a t}
$$

2. If the value of the $\mathrm{P}_{\mathrm{RE}}(\mathrm{t})<\mathrm{P}_{\mathrm{L}}(\mathrm{t})$ insufficiency power will be supplied by diesel generators and/or the battery banks according to the following dispatch strategy:

- If the amount of power from battery banks is enough to handle the remaining power, the strategy allows the discharging process of battery banks with following equation [14]:

$$
C_{B a t}(t)=C_{B a t}(t-1)+\left(P_{p v}(t)-\frac{P_{L}(t)}{\eta_{i n v}}\right)
$$

Where, $\mathrm{C}_{\mathrm{Bat}}(\mathrm{t})$ is available battery banks capacity at hour $\mathrm{t}, \mathrm{C}_{\mathrm{Bat}}$ (t-1) is available battery banks at previous hour and $\eta_{\text {Bat }}$ is yield of battery charging.

The value of $C_{B}(t)$ could not be lower than minimum allowable energy level remained in battery banks, and it could not be higher than maximum allowable energy level during charging operations as follow $[8,13]$ :

$$
\mathrm{C}_{\mathrm{Bmin}} \leq \mathrm{C}_{\mathrm{B}}(\mathrm{t}) \leq \mathrm{C}_{\mathrm{Bmax}}
$$


- Whenever battery banks are fail to supply the remained power or the strategy does not allow for the battery banks to discharge, then diesel generator is started and battery banks will be neither charged.

$$
P_{D G}(t)=P_{L}(t)-P_{R E}(t)
$$

Where, $\mathrm{P}_{\mathrm{DG}}(\mathrm{t})$ is the output power from diesel generator unit.

\subsection{Diesel generator}

The fuel consumption of diesel generator unit is related with the rated power and its generated power. The fuel cost is calculated for a year as follows [15]:

$$
A F C=C_{f} \sum_{t=1}^{T e n d} F(t)
$$

Where, $F(t)$ is the hourly fuel consumption (liter/hour), based on load characteristic of the diesel generators. This parameter is calculated as follows [14]:

$$
F(t)=\left(0.246 \times P_{D G}(t)+0.08415 \times P_{R}\right)
$$

Where, $P_{R}$ is rated power of diesel generators, $P_{D G}(t)$ is the power generated by diesel generators and $\mathrm{C}_{\mathrm{f}}$ is the fuel cost per liter in US\$/1.

\section{Description of the LPSP method}

A balanced system, the amount of energy supplied by the solar modules must at least compensate the amount of energy, depending on the place of installation, the season, and the particular conditions of consumption and use.

The sizing method presented consists in determining the optimum number of batteries and PV modules according to an optimization criterion, namely reliability, which is based on the concept of the LPSP (Loss of Power Supply Probability), It will allow us to dimension a realistic electricity production system supplying ten individual habitats for the Djanet site during a year.

Dimensioning a PV system means determining all the elements of the PV chain according to the loads such as the sunshine and the load profile. There is no fixed scale between consumption and generator size. There are several methods of dimensioning a PV system: by the hourly usability function, by the probability of energy loss, and by iterative methods ... etc.

LPSP is a probability technique introduced by AbouZahr and Ramakumar in 1990 the field of wind and photovoltaic generation systems $[16,17]$. The probability of energy loss (loss of power supply probability) is widely used in the design and optimization of autonomous systems (stand-alone) wind-photovoltaic [18, 19, 20]. It is based on the concept of the LPSP, which is the probability that the system is experiencing a shortage at some time during a period of analysis, that is to say a state in which the system would not be able to provide energy to the load. From the information on the variability of resources and its correlation with the load, LPSP can be calculated. This method is particularly useful in assessing the behavior of an energy storage.

The 'LPSP' is defined as the fraction of the unsatisfied demand on that requested by the load. It expresses the rate of nonsatisfaction of the load. Thus, this probability is defined as the sum of all unfulfilled demands 'LPS' on the total energy demanded by the load during a period of operation (For this study, $\mathrm{T}=1$ year), as follows [14] :

$$
L P S P=\frac{\sum_{t=0}^{T} T_{i}}{T_{p}}
$$

Where,

$\mathrm{T}_{\mathrm{p}}$ is the period of study.

$\mathrm{T}_{\mathrm{i}}$ is the duration corresponding to a power produced less than the demand.

\section{Application of the LPSP to the PV installation}

The first step before carrying out any dimensioning is to determine when we need electricity and to define our consumption which should not be underestimated or overestimated. This step requires a lot of reflection because an error at this stage will distort our results. So, at the outset, we choose the energy consumption profile, as well as the choice of an architecture of the system.

With the data from the first step, you will be able to know the number of photovoltaic modules needed to cover the electricity needs. To do this, it is necessary to calculate the energy that the modules must produce each day, and to know the sunshine of the region where the installation is located. The amount of electricity produced by the photovoltaic modules depends directly on this sunshine and therefore on the region.

Always the first step will also allow us to calculate the number of battery. The stored energy depends directly on the periodicity of your consumption.

The next step is to dimension the load regulator. This step does not involve any calculation, but there are a wide variety of regulators that differ according to their options, functions and power. It will therefore take time to choose the regulator best suited to your situation.

Another step is to choose the converter if this device is necessary, that is to say if our load is operating in AC mode. Indeed, the installation can already provide direct current 12, 24 or 48VDC.

\section{Development of the proposed approach}

The system configuration is shown in Figure 5; meanwhile, the flowchart of system operation is shown in Figure 7. The load demand is supplied by DGs, PV, and battery banks. The bidirectional inverter is required to supply power from battery banks to the load demand or feed surplus power from PV panels and DGs to the battery banks. Total power from battery banks, DGs and PV panels has to satisfy the load demand. The concept of operational strategy could be explained clearly as follow:

- If the load demand $\left(\mathrm{P}_{\mathrm{L}}(\mathrm{t}) / \eta_{\text {inv }}\right)$ is less than the total power produced from photovoltaic panels $\left(\mathrm{P}_{\mathrm{pv}}(\mathrm{t})\right)$, and the battery $\mathrm{C}_{\mathrm{B}}$ is fully charged, then the banks of the battery are charged as amount as the capacity of the inverter and the excess power are dumped. 


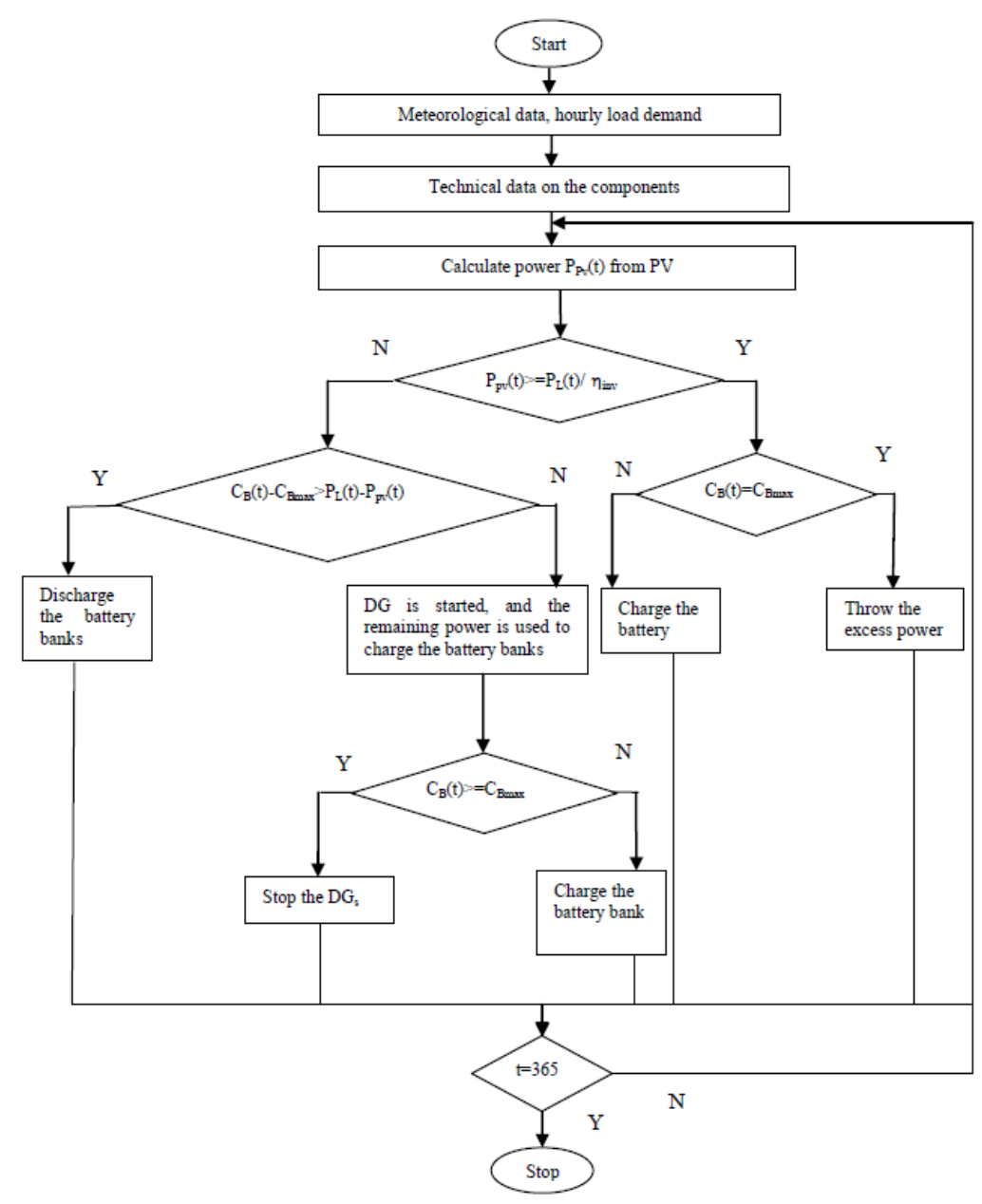

Figure 7: Flowchart of the algorithm for simulating hybrid system

- If the $C_{B}(t)$ is less than $C_{B m a x}$ the excess power is used to charge the banks of the battery.

- If the load demand $\left(\mathrm{P}_{\mathrm{L}}(\mathrm{t}) / \eta_{\text {inv }}\right)$ is greater than $\mathrm{P}_{\mathrm{pv}}(\mathrm{t})$ and $\mathrm{C}_{\mathrm{B}}$ (t) of the banks of the battery is greater than $\mathrm{C}_{\mathrm{Bmin}}$, then the power of the insufficiency will be provided by the banks of the battery. Otherwise, if $\mathrm{C}_{\mathrm{B}}(\mathrm{t})$ of the battery banks equal $\mathrm{C}_{\mathrm{Bmin}}$, diesel generators are started to meet the demand for charging the banks of the battery.

- However, if the power of the inadequacy is greater than the capacity of the inverter, the battery banks are discharged in quantity that the capacity of the inverter, and then the diesel generators are started to meet the load demand.

\section{Application and results}

The main objective of this work is to determine the optimal configuration of the hybrid photovoltaic, diesel generator with storage to satisfy the power demanded by the load.

Several methods of designing hybrid energy systems have been carried out by researchers. The method we are going to use is based on a technical-economic analysis. We will first apply the LPSP

Table 1: Number of PV modules in terms of LPSP

\begin{tabular}{|c|c|c|c|}
\hline LPSP & $\mathbf{0 . 0 1}$ & $\mathbf{0 . 0 2}$ & $\mathbf{0 . 0 3}$ \\
\hline Number of PV modules & 221 & 219 & 216 \\
\hline Number of batteries & 120 & 105 & 90 \\
\hline Number of diesel generators & 3 & 3 & 2 \\
\hline
\end{tabular}

\begin{tabular}{|l|c|c|c|c|}
\hline & $\begin{array}{c}\text { Energy } \\
\text { produced } \\
\text { by PV } \\
\text { (kWh) }\end{array}$ & $\begin{array}{c}\text { Average } \\
\text { storage } \\
\text { capacity } \\
\text { (kWh) }\end{array}$ & $\begin{array}{c}\text { Fuel } \\
\text { consumption } \\
\text { (Liter) }\end{array}$ & $\begin{array}{c}\text { The } \\
\text { operating } \\
\text { hours of } \\
\text { DG }\end{array}$ \\
\hline January & 1300 & 88.6046 & 6,33 & 1,00 \\
\hline February & 1420 & 87.8545 & 0,00 & 0,00 \\
\hline Marche & 1620 & 97.2668 & 0,00 & 0,00 \\
\hline April & 1550 & 54.4687 & 88,62 & 14,00 \\
\hline May & 1650 & 54.4379 & 82,29 & 13,00 \\
\hline June & 1440 & 48.3240 & 151,92 & 24,00 \\
\hline July & 1440 & 49.8778 & 177,24 & 28,00 \\
\hline August & 1640 & 51.8210 & 88,62 & 14,00 \\
\hline September & 1550 & 52.6139 & 101,28 & 16,00 \\
\hline October & 1690 & 96.4810 & 0,00 & 0,00 \\
\hline November & 1350 & 87.1510 & 0,00 & 0,00 \\
\hline December & 1170 & 85.6003 & 0,00 & 0,00 \\
\hline
\end{tabular}

Table 3 : Annual energy balance

\begin{tabular}{|c|c|}
\hline Nature & Value \\
\hline Annual PV Energy produced & $17820 \mathrm{kWh}$ \\
\hline Average annual storage capacity & $69,90 \mathrm{kWh}$ \\
\hline Annual fuel consumption & $696,30 \mathrm{Liters}$ \\
\hline Annual energy produced by diesel generator & $2200 \mathrm{kWh}$ \\
\hline Annual excess energy & $4030,8 \mathrm{kWh}$ \\
\hline
\end{tabular}


(Loss of Power Supply Probability) method. Then, using the optimal configuration that satisfies the demand obtained, consisting of the number of photovoltaic panels, number of batteries and diesel generators, we use the approach proposed in the previous section to simulate the hybrid system.

In our system, we chose LPSP $=0.03$ which gives a number of PV modules equal to 216 Depending on weather conditions (light and temperature) and load profile, the number of photovoltaic modules is given in Table 1 .

Table 4 : Daily production percentage

\begin{tabular}{|c|l|}
\hline Nature & Percentage \\
\hline Photovoltaic & $94.4627 \%$ \\
\hline Diesel Generator & $5.5373 \%$ \\
\hline Annual excess energy & $1.5229 \%$ \\
\hline
\end{tabular}

Table 1 show that by increasing the value of the LPSP, the number of PV panels, battery banks and diesel generators is decreased. In other words, the variation of components depends on the LPSP.

It is thus possible to conclude from various simulations that the availability of photovoltaic panels plays a key role in the optimal system design and in the precise design of the energy production of the system.

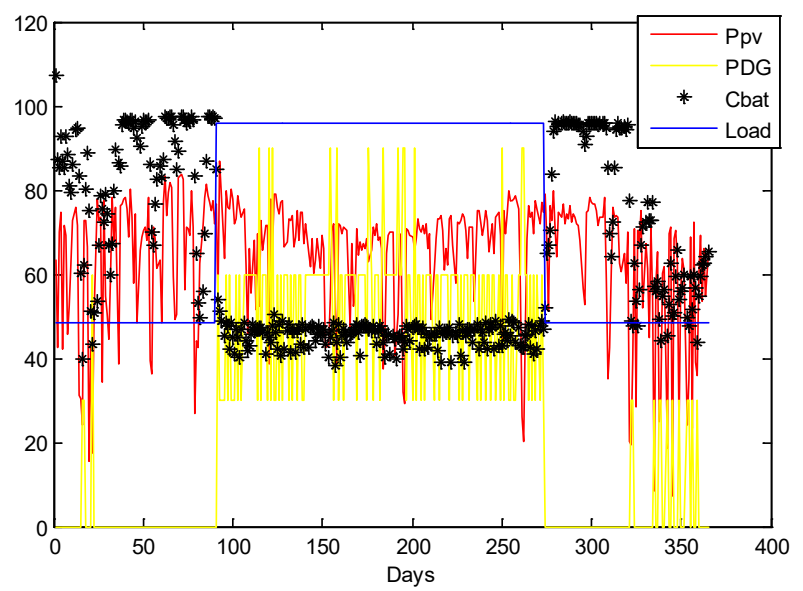

Figure 8. The energy management of hybrid system

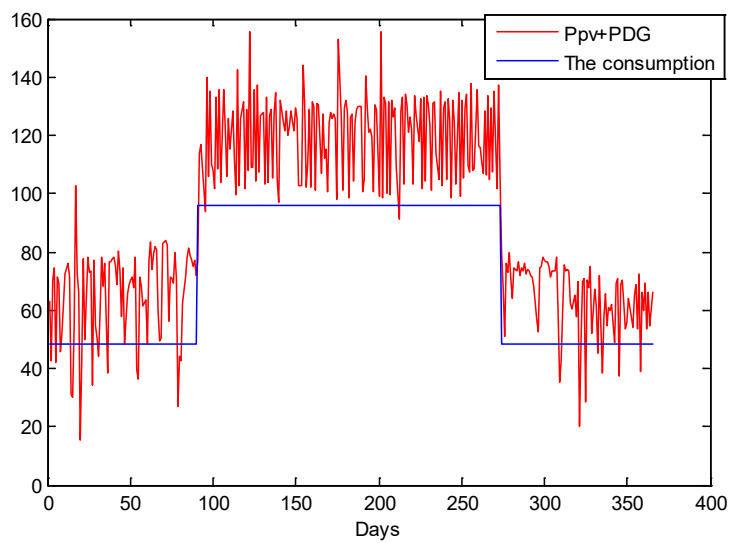

Figure 9: The daily power generated by PV panels and $\mathrm{DG}_{\mathrm{s}}$ compared with the consumption

The simulation results presented in this paper provides monthly, hourly and daily results, which allows us to make monthly and annual balance sheets. Figure 8 shows a monthly variation in the production of photovoltaic energy, diesel generators and average storage capacity respectively, we see that the two production pikes are for the months of April and
September (iterations 93 and 279), and production is minimal in the month of December (in the iteration 345), these results affect the ability of storage, the relationship between the two parameters is proportional.

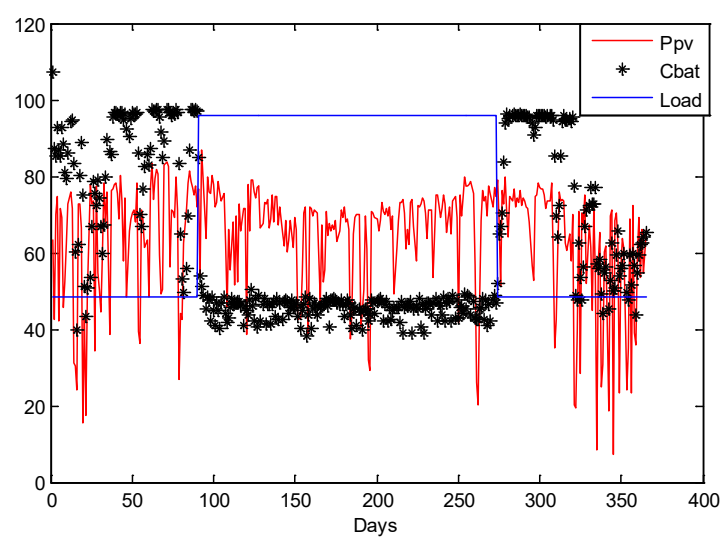

Figure 10: energy management of only PV system

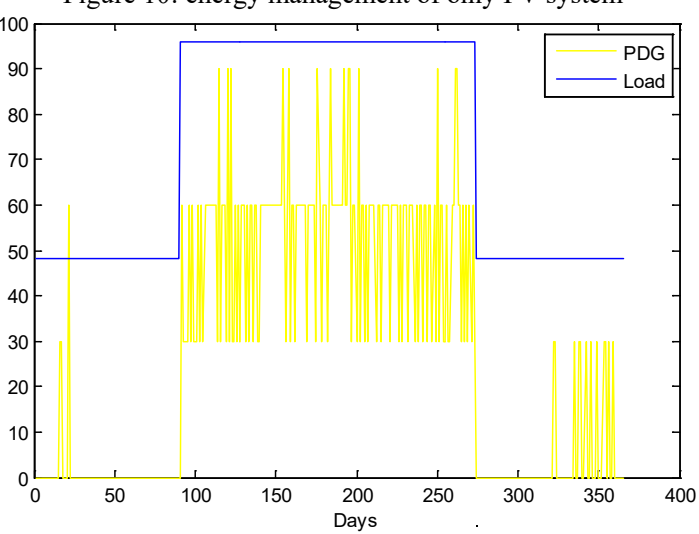

Figure 11: energy management of only DG system

The energy produced by the diesel generator, as shown in Table 3 vary from one month to another, they are highest in the months of April, May, June (in the iterations 92 to 272), and they are minimal in the months of January, February, March, April, May, October, November and December (in the iterations 1 to 91 and 273 to 365 ). Note that the results are synchronized by sunshine, temperature and load, we also find that the percentage of photovoltaic is important $(94.4627 \%)$ by contribution to $5.5373 \%$ of the energy produced by the diesel generator.

The excess energy is low in the order of $1.5229 \%$. The energy produced by the system during 12 months compared with the consumption is shown in Figure 9. it can be observed that the consumption is minimum in the months of January, February, March, October, November and December (in the iterations 1 to 88 and 274 to 365 ), which is causing a decrease in the total energy produced, and it increases proportionally with consumption in the rest iterations (months of April, may, June, July, August and September).

The simulation results of only PV system, only DG system are presented in Figures 10 and 11 respectively. From these results it can be concluded that the system is able to fully satisfy the load demand.

The design procedure resulted in determination of best configuration of the system.

The stand-alone hybrid PV-DG system with battery bank seems to be a motivational techno-economic solution to meet the energy demand of consumer. 


\section{Conclusion}

This paper presents a new method based on loss power supply probability (LPSP) to solve the optimal sizing of a hybrid PV/Diesel/Battery system. The optimal number of PV panels, Diesel generators and batteries is determined using LPSP to supply the load. The main objective of this work is to examine the feasibility and performance to electrify rural community by the hybrid solution, then we realized that the operation of the system depends not only on the input and output variables which are the sunshine, the temperature and the load to be supplied but also the interdependence between different devices. An improperly sized system component can compromise which was verified by simulation results the proper functioning of the entire system. Thus, we can conclude that the combination of energy sources (PV-Diesel-Battery) is required to be able to cover the energy deficit and meet the growing energy demand of rural inhabitant. We believe that the technical and economic simulation results obtained were satisfactory and demonstrated the effectiveness of the studied hybrid system.

A successful hybrid system requires an energy saving approach and a rigorous design and installation of components that meet the need.

\section{Conflict of Interest}

The authors declare no conflict of interest.

\section{Acknowledgment}

The research work presented in this paper was jointly carried out by the Research Laboratory in Electrical Engineering and Automatics (LREA) at the University of Yahia Fares in MedeaAlgeria and the Control Laboratory Processes (LCP) at the National Polytechnic School of Algiers-Algeria. We would like to thank all those involved in our project.

\section{References}

[1] T. A Khatib, "Review of designing, installing and evaluating standalone photovoltaic power systems" Journal of Appl. Sciences.,;10:1212-28, 2010.

[2] R. Mukund, "Wind and solar energy" CRC Press LLC., 1999.

[3] The German solar energy society, "Planning and installing photovoltaic systems", 2005.

[4] M. Ashari, V. Nayar, "An optimum dispatch strategy using set points for a photovoltaic (PV)-diesel battery hybrid power system" Sol. Ener., 66:1-9, 1999.

[5] A. Yahiaoui, K. Benmansour, M. Tadjine, "A new sizing algorithm of renewable hybrid systems PV-Diesel Generator-Battery: application to the case of Djanet city of Algeria" 8th International Conference on Modelling, Identification and Control (ICMIC), Algeria, 2016

[6] E. Koutroulis et al, "Methodology for optimal sizing of stand-alone photovoltaic/wind generator systems using genetic algorithms" Sol. Ener. Volume 80, Issue 9, Pages 1072-1088, 2006.

[7] H. Yang et al, "a novel optimization sizing model for hybrid solar-wind power generation system" Sol. Ener., Volume 81, Issue 1, Pages 76-84 2007.

[8] R. Hosseinalizadeh et al, "Economic sizing of a hybrid (PV-WT-FC) renewable energy system (HRES) for stand-alone usages by an optimization-simulation model: Case study of Iran" Renew. Sust. Ener. Rev., Volume 54, Pages 139-150, 2016.

[9] B. Guinot et al, "Techno-economic study of a PV-hydrogen-battery hybrid system for off-grid power supply: Impact of performances' ageing on optimal system sizing and competitiveness" Inter. Journal of Hydro. Ener. Volume 40, Issue 1, Pages 623-632, 2015.

[10] T. Senjyu, D. Hayashi, A. Yona, N.Urasaki and T. Funabashi, "optima configuration of power generating systems in isolated island with renowable energy" Renew. Ener., vol.32, PP. 1917-1933, 2007

[11] B. Nelson, M. H. Nehrir, C. Wang, "unit sizing cost analysis of stand-alone hybrid wind/PV/fuel cell power generation systems" Renew. Ener, vol. 31 PP. 1641-1656, 2006.

[12] A. Yahiaoui, K. Benmansour, M. Tadjine, "Control, analysis and optimization of hybrid PV-Diesel-Battery systems for isolated rural city in Algeria" Sol. Ener, vol. 137: 1-10, 2016.
[13] H. Suryoatmojo, A. A. Elbaset, F. A. Pamuji, D.C. Riawan, Nursalim, M. Abdillah, "optimal sizing and control strategy of hybrid PV-Diesel-Battery systems for isolated island" ADCONP 2014 Hiroshima.

[14] B. S. Borrowy, Z. M. Salameh, "Methodology for optimally sizing the combination Battery Bank and PV array in a Wind/PV hybrid system" IEEE Trans. Ener. Conv, Vol. 12, N¹, pp. 73-78, 1997.

[15] H. Suryoatmojo, A. A. Elbaset, T. Hiyama, "Economic and reliability evaluation of Wind-Diesel-Battery system for isolated island considering $\mathrm{CO}_{2}$ emission" IEEJ Trans. PE, vol. 129(8), 2009.

[16] I. Abouzahr, R. Ramakumar, "Loss of power supply probability of standalone wind electric conversion systems" IEEE Trans. Ener. Conv, vol. 5, ${ }^{\circ}$ 3, pp. 445-452, 1990 .

[17] I. Abouzahr, R. Ramakumar, "Loss of power supply probability of standalone photovoltaic systems", IEEE Trans. Ener. Conv, vol. 6, n 1, pp. 1-11, 1991.

[18] F. M. A. Ghali, M. M. Abd El Aziz, F. A. Syam, "Simulation and analysis of hybrid systems using probabilistic techniques" Proceedings of IEEE Power Conversion Conference, Nagaoka, pp. 831-835, 1997.

[19] F. Giraud, Z. M Saameh, "Steady-state performance of a grid-connected rooftop hybrid wind-photovoltaic power system with battery storage" IEEE Trans. Ener. Conv, ISBN 0885-8969, vol. 16, n 1, pp. 1-7, 2001.

[20] Enrico Fabrizio, "modeling of multi energy systems in buildings", $\mathrm{PhD}$ Thesis, National Institute of Applied Sciences in Lyon, in July 2008. 